\title{
一般口演 9
}

\section{ディスポーザブルプローブを用いて \\ 舌運動リハビリテーションを行った口腔癌症例}

Oral cancer patients successfully rehabilitated using disposable intraoral pressure probe.

\author{
○歌野原有里 ${ }^{*}$, 林 亮*,**, 吉田光由*, 久保隆靖***, 津賀一弘*, \\ 藤原百合 ${ }^{* * *}$, 岡本哲治*, 鎌田伸之* , 赤川安正 ${ }^{*}$ \\ Yuri UTANOHARA ${ }^{*}$, Ryo HAYASHI ${ }^{*}{ }^{* *}$, Mitsuyoshi YOSHIDA ${ }^{*}$, Takayasu KUBO ${ }^{* * *}$, Kazuhiro TSUGA ${ }^{*}$, \\ Yuri FUJIWARA ${ }^{* * *}$, Tetsuji OKAMOTO ${ }^{*}$, Nobuyuki KAMATA ${ }^{*}$, Yasumasa AKAGAWA * \\ ${ }^{*}$ 広島大学大学院医歯薬学総合研究科, ${ }^{* *}$ 長寿科学振興財団, ${ }^{* * *}$ 広島大学病院 \\ * Hiroshima University Graduate School of Biomedical Sciences, \\ ** Japan Foundation for Aging and Health, ${ }^{* * *}$ Hiroshima University Hospital
}

\section{I. 緒言}

舌は咀嚼，嚥下，発音などに重要な役割を果たして いる. 舌の機能低下に対しては可動域の拡大，筋力の強 化，巧緻性獲得を目的とした運動訓練 ${ }^{1)}$ が行われてお り，様々な評価法が考案されている。しかしながら，特 に筋力について訓練効果を定量的に評価し，効果的にリ ハビリテーションを行う方法は確立されていない.

今回, 口腔癌切除·再建手術後摂食・嶼下·発音に支 障をきたしている 3 症例に対して, 本学で開発したディ

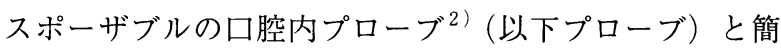
易型舌圧測定装置を利用して, 舌の筋力の指標となり得 る舌圧の定量評価とリハビリテーションを試み，臨床的 改善を認めたので報告する。

\section{II. 方 法}

対象：広島大学病院に入院，または通院中の口腔癌切 除・再建手術を受けた 3 症例（後述）とした.

診査項目 : (1)口腔内状況(2)舌の運動機能（視診にて前方 突出, 左右側方, 舌尖の挙上運動を評価)

(3)構音機能（「ぱ」,「た」,「か」,「ら」の 4 語を評価） (4)燕下時所見（肉眼または臙下造影（VF）にて評価）
(5)最大舌圧（プローブを用いた簡易型舌圧測定装置を使 用して, 最大の舌圧で 7 秒間風船を口蓋との間で押し潰 したときの最大值を最大舌圧として測定）

訓練方法：定期的に最大舌圧を測定し, 症例ごとに効果 の確認および方法を検討した。ささらに，得られた結果を 随時対象者に提示することでモチベーションの向上を目 指した。

\section{III. 症例}

症例 $1: 69$ 歳，女性

主 訴：器質性構音障害および曣下障害

現病歴：左側舌半側切除術と大胸筋皮弁に上る再建術を 行い，摂食補助床（PAP）製作のため耳鼻科より紹介で 来院.

現 症：舌の挙上が不十分で「か」,「ら」の発音が不明 瞭である.

リハビリテーション：舌尖の挙上をはじめとする舌可動 域の拡大を目標として，プローブを口蓋皺壁上に位置さ せ，最大の舌圧でできる限り口蓋に押しつぶすよう指示 した。

臨床経過：PAPの調整を行いながら在宅にて訓練を行っ た。訓練開始 3 力月後，摂食状態の改善が認められたた 


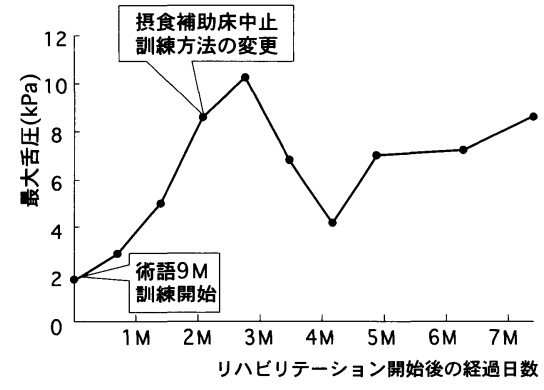

図1リハビリテーション経過

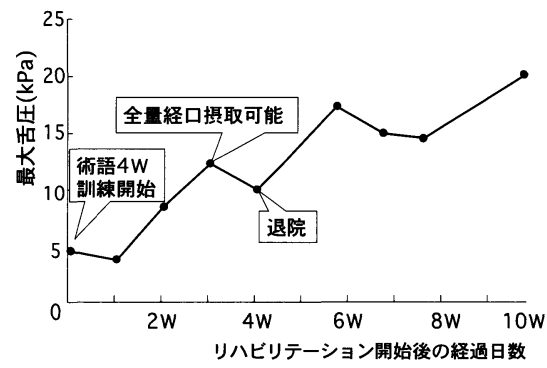

図 2 リハビリテーション経過

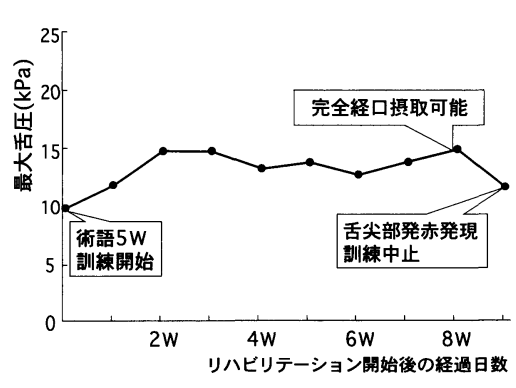

図 3 リハビリテーション経過
めPAPの使用を中止したが，口腔底部から頝部にかけて 疼痛が発現したため一時訓練を中止し, 疼痛緩和後, 方 法を変更して訓練を再開した（図 1). 7 力月後, 舌の 前方 ·挙上運動の改善,「か」「ら」の明瞭化, また, 飲 み込みの改善, むせの減少, 口腔内残留物の減少, 食生 活の改善が見られた。

症例 $2: 73$ 歳, 男性

主 訴：器質性構音障害および燕下障害

現病歴：下顎歯肉癌により腫瘍切除術, 下顎骨区域切除 術, 左側全䅡部郭清術, 右側上頚部郭清術を行い, プレー トおよび大胸筋皮弁による同時再建術を行った.

現 症：「た」と「ら」が不明瞭で舌の前方・側方・挙 上運動の制限を認めた。ささに，VFより舌口蓋閉鎖不 全による舌背への残留と, 早期咽頭流入を確認した.

リハビリテーション：舌尖の挙上をはじめとする舌可動 域の拡大を目標として, 朝夕 3 回ずつ 7 秒間, プローブ を口蓋に最大の舌圧で押しつぶすよう指示した。

臨床経過：訓練開始時最大舌圧は $4.6 \mathrm{kPa}$ で 3 週間後全量 経口摂取が可能となり，4週間後に退院，その後も訓練 を継続した。訓練開始 10 週目，最大舌圧は20.0kPaであ り（図 2 ), 舌の前方·側方·挙上運動の改善，「た」「ら」 の明瞭化，また，舌背食物残留の減少，むせの減少，飲 み込みの改善が見られた。

症例 $3: 63$ 歳, 男性.

主 訴：器質性構音障害および嚥下障害

現病歴：口底癌により腫瘍切除術, 下顎骨区域切除術 を行い，プレートおよび遊離腹直筋皮弁による再建術を 行った.

現 症：「た」と「ら」が不明瞭. 舌の前方・側方・挙 上運動の制限，VFより舌背の挙上不足による口腔内残 留, 早期咽頭流入, 舌喉頭の動きの不調和, 喉頭流入を 認めた。

リハビリテーション：舌尖の挙上をはじめとする舌可動 域の拡大を目標として, 朝昼夕 3 回ずつ 7 秒間, プロー
ブをロ蓋に最大の舌圧で押しつぶすよう指示した。

臨床経過：訓練開始時最大舌圧は $9.8 \mathrm{kPa}$ で 9 週後全量経 口摂取が可能となった。しかし，1週後に舌尖部の発赤 を認めたため訓練を一時中止（最大舌圧 $13.9 \mathrm{kPa}$ ）した. 発赤消退後，訓練方法を変更したが，再度発赤が見られ たため訓練を完全に中止した（図 3 ). その後，言語訓 練を継続し14週後に退院となった。この際, 舌の挙上運 動の改善,「た」の明瞭化, 舌背食物残留の減少, むせ の減少, 飲み込みの改善が見られた.

\section{V. 考察}

本装置を用いて最大舌圧の測定とリハビリテーショ ンを行い, 舌機能を数值として患者にフィードバックす ることができた。このことにより訓練に対するモチベー ションの向上がみられ，積極的なリハビリテーションを 行うことができた．また，本プローブは被験者自身の手 で保持するのに適切な形状と長さを有しており，構造も シンプルであることから患者個々に合せてリハビリテー ション方法を検討することも可能で，舌尖，奥舌など症 例ごとに必要と考えられる位置への設定が容易である. さらに，プローブの風船部分は口腔の状態に応じて大き さを調節することもでき，多様な症例に応用できると考 えられる。

以上より，舌の運動機能低下に対する本装置を用いた リハビリテーションの有用性が示唆された.

\section{N. 文献}

1）金子芳洋, 千野直一：摂食・嚥下リハビリテーショ ン, 175-178, 医歯薬出版, 東京, 1998

2 ) Hayashi, R., Tsuga, K., Hosokawa, R. et al: A novel handy plobe for tongue pressure measurement, Int $\mathrm{J}$ Prosthodont, 15: 385-388, 2002. 